DOI: 10.32370/IA_2021_09_13

\title{
Specifics of the Concert Master's Pedagogical Activity in the Context of Trends of Modern Art Education
}

\author{
Koresandovich Natalia Mykolayivna, \\ applicant of the Kyiv National \\ University of Culture and Arts, \\ Kyiv, Ukraine
}

\begin{abstract}
The article considers the problems of pedagogical activity of the accompanist through the prism of the peculiarities of the development of art education in the first decades of the XXI century.

It is stated that the current stage in the pedagogy of concertmaster activity is characterized by the presence of formed and developed by specialists in various fields of science basic concepts, scientific and methodological principles, methods of artistic and aesthetic education of future musicians. It was found that the issue of pedagogical competence of the accompanist is one of the urgent problems, as each historical stage of development of society, forming its own guidelines for art pedagogy, makes new demands or modifies existing ones. It is noted that the problems of concertmaster activity in the context of art education at the present stage are determined by the nature and content of the conditions that characterize the life of modern society.

It is emphasized that the prospects for the development of pedagogical activities of the accompanist include educating future artists of the best artistic and aesthetic qualities, creating in the learning process conditions for comprehensive personal development, meeting professional and spiritual needs, developing their creative abilities and skills of artistic research.

The specifics of the development of modern art education involves the transformation of traditional methods and approaches to teaching in order to adapt to the requirements of modern students, as well as - to the conditions of socio-cultural space.
\end{abstract}

Key words: accompanist, pedagogical activity, modern art education, performance, music-educational process, creativity.

Актуальність дослідження. Діяльність концертмейстера (виконавська, організаційна, педагогічна) унікальна власною поліфункціональністю, що передбачає органічне поєднання амплуа концертмейстера, педагога та співучасника дії.

В умовах сучасної мистецької освіти складно уявити навчальну роботу у вокальних та інструментальних класах освітніх закладів без концертмейстера, діяльність якого стала більш складною та багатоплановою, що зумовлено посиленням вимог до професійного рівня, необхідністю розробки універсальних критеріїв професійної майстерності концертмейстера, які включають ряд необхідних особистісних якостей.

Теоретико-практичний дискурс педагогічної діяльності концертмейстера у цьому контексті зазнає відчутних змін, що зумовлює актуальність дослідження даного аспекту проблематики концертмейстерства. 
Аналіз публікацій. Історія концертмейстерства як виду музичної практики нараховує кілька століть, практично з часів середньовічних мандруючих музикантів менестрелів, жонглерів та шпільманів. Проте і на сучасному етапі розвитку гуманітарного знання, досліджень, що надавали б цілісне уявлення про базові принципи та специфічні особливості концертмейстерської діяльності недостатньо. Це пояснюється тривалим культивуванням даного виду музичної діяльності в галузі аматорського музикування та позиціюванням його супутнім видом занять в творчій діяльності виконавця-професіонала. Водночас аналіз останніх досліджень та публікацій засвідчує активізацію наукового інтересу до проблематики педагогічної майстерності концертмейстера. Наприклад, О. Щербінін у науковій публікації «Професійна діяльність музиканта-педагога: сучасні вимоги та критерії оцінювання» [11] обгрунтовує вимоги до фахівців музично-педагогічної галузі, здійснюючи спробу виявити специфіку оперування відповідними спробами передачі власного творчого досвіду; О. Переверзєва в статті «Педагогічні аспекти професійної діяльності концертмейстера у загальнокультурному та музично-естетичному розвитку майбутнього вчителя музичного мистецтва» [9] аналізує професійну діяльність концертмейстера відповідно до специфіки системи закладів вищої освіти, акцентуючи на дослідженні доцільності трансформацій та доповнень з метою удосконалення професійної підготовки концертмейстерів в умовах спеціальних освітніх закладів; В. Зорін у публікації «Педагогічна майстерність піаністаконцертмейстера» [4] висвітлює методологію діяльності піаніста-концертмейстера; О. Умрихіна та А. Подолян у науковій розвідці «Роль піаніста-концертмейстера в педагогічній освіті» [10] розглядають педагогічний аспект діяльності концертмейстера в контексті успішного виховання педагога-музиканта; Р. Гургула та I. Сфремова в публікації «Педагогічний аспект підготовки майбутнього піаніста-концертмейстера» [3] зосереджують увагу на вивченні психолого-педагогічної площини навчання піаністівконцертмейстерів у педагогічному коледжі та ін.

У даному дослідженні педагогічна діяльність концертмейстера розглядається крізь призму особливостей та тенденцій розвитку сучасної мистецької освіти.

Мета статті - виявити особливості педагогічної діяльності концертмейстера в контексті особливостей розвитку мистецької освіти в перші десятиліття XXI ст. 
Виклад основного матеріалу. В сучасному науковому вітчизняному та закордонному вимірі розуміння та осмислення концертмейстерства суттєво відрізняються, що зумовлено різницею термінології - «concertmaster» в більшості країн трактується як «перша скрипка в оркестрі», натомість педагог, який допомагає музикантам у процесі навчання вивчати партії, а також акомпанує інструменталістам і вокалістам - терміном «ріanist» [3, с. 26].

Головною особливістю професійної діяльності концертмейстера є комплекс його виконавських та тактико-психологічних вмінь, що окрім вміння чути власне виконання, передбачає знання партії партнера та навички органічно реагувати на ситуативний контекст з метою демонстрації слухачам цілісної виконавської інтерпретації [7, с. 128]; концертмейстер має чітко передавати головні параметри стилю музичного твору, співвідноситись з індивідуальністю соліста та явити власне обличчя в сумарному виконавському результаті.

Концертмейстерство, як творча багатопрофільна діяльність піаніста, включає в себе базові константні компоненти - власне адресант, музикант-художник широкої кваліфікації та його спеціальні ансамблеві навички, психологічні якості, педагогічні та організаційні здібності.

Професійна підготовка кадрів для повноцінної в творчому відношенні діяльності в усіх галузях музичного мистецтва, виховання естетично розвинутих та самостійно мислячих музикантів, ставить в галузі музичної освіти серйозні завдання як перед педагогами, так і перед концертмейстерами. Відповідно, зростають вимоги до професійної майстерності, що включає не лише високий в художньому та технічному відношенні рівень володіння виконавськими та психологічними навичками і прийомами, але й педагогічними компетенціями, що передбачає знання педагогічних аспектів професійної діяльності, специфіку мистецької педагогіки та вміння застосовувати власні знання на практиці.

Функції концертмейстера мають педагогічний характер, оскільки участь у виборі педагогом програми i спільне вивчення музичного твору сприяють розвитку музикальності та індивідуальності соліста. Відповідно педагогічний бік діяльності піаніста вимагає використання власного концертмейстерського досвіду, зокрема виразного виконання, що сприяє сприйняттю форми, метроритму, ладу та інших засобів 
художньої виразності, а також ряду спеціальних умінь та навичок в галузі суміжних виконавських дисциплін, знань в галузі психології та педагогіки. Л. Баренбойм наголошує, що концертмейстер має бути наділений відчуттям професійної відповідальності за художній результат, культурою спілкування та проявляти педагогічний такт, витримку, оптимізм у вирішенні поставлених завдань [1, с. 27].

Діяльність концертмейстера передбачає співпрацю 3 представниками різних художніх спеціальностей (наприклад, інструменталістами та вокалістами, хоровими колективами, вокальними, інструментальними i хореографічними ансамблями). Відповідно, він має бути музикантом-універсалом, який зазвичай виконує і педагогічні функції.

Педагогічні аспекти діяльності концертмейстера базуються на всебічному аналізі твору, визначенні стилістичних особливостей, технічних труднощів та виконавських засобів сценічної виразності.

На думку В. Калініної, професійний концертмейстер - важлива ланка в складному ланцюгу музично-навчального процесу, а суть його роботи полягає в забезпеченні художньої творчості партнера або партнерів засобами музичного супроводу, що доцільно розглядати як один зі способів педагогічної діяльності [5, с. 8].

Основою змісту та структури творчої діяльності концертмейстера є педагогічна концепція розвиваючого навчання, відповідно до якої робота над удосконаленням професійних музично-виконавських знань, навичок та вмінь партнера або партнерів знаходиться в тісному зв'язку з універсальним розвитком індивіда, розширенням його художніх знань та загальнокультурної ерудиції, активізацією творчих та пізнавальних можливостей.

В. Кононено акцентує на тому, що сама природа концертмейстерського мистецтва призначена для виховання музичної культури майбутніх вчителів музики, як частини всієї їх духовної культури, в єдності з педагогічною технологією забезпечення цього процесу [6, с. 3].

Педагогічний аспект роботи концертмейстера складається 3 гностичного, конструктивного, комунікативного та організаційного компонентів. Концертмейстер, який створює атмосферу спільного пошуку, співтворчості, що допомагає учню розширити власні можливості, повинен володіти мастерністю педагогічної імпровізації. 
Дослідники наголошують, що фундаментальною основою навчально-виховного процесу, з якого походять всі його аспекти, повинно виступати розуміння педагогічної спрямованості професії концертмейстер як виховання спільних способів музичнохудожньої діяльності. Зокрема, в навчальному курсі «Концертмейстерський клас» корінне протиріччя художньої освіти в цілому між призначенням та змістом мистецтва i методами його вивчення та викладання конкретизується в протиріччі між сутністю «мистецтва концертмейстера» як фундаменту художнього розвитку педагога-музиканта та організацією цього процесу з поцій формування лише професійних знань, вмінь та навичок. Відповідно комплекс «специфічних» концертмейстерських навичок на вмінь, що традиційно виділяється на практиці, має змінити свій статус і бути переосмислений як універсальна «технологія» музичного виконавства [6, с. 19].

Водночас теоретики та практики концертмейстерської діяльності констатують, що жоден навчальний заклад не в змозі сформувати «закінченого концертмейстерапрофесіонала» [2, с. 25], а лише дає принципи, базові навички та знання в галузі концертмейстерства, які надалі індивід удосконалює самостійно протягом всієї професійної кар'єри.

Однією з тенденцій сучасної музичної педагогіки $є$ зміна визначення статусу концертмейстера як педагога-репетитора або, відповідно до західної термінології, «коуч». Наприклад, Л. Курицькою вперше здійснено спробу адаптування коучінгового підходу, що передбачає, окрім виконання традиційних функцій, пов'язаних із художньовиконавськими компетенціями музиканта, виконання психологічних, організаційних та консультативних функцій, зокрема:

- формування мотивації учня та його психологічної готовності до концерту;

- підтримка в процес подолання труднощів;

- емоційна підтримка та емпатія;

- планування та координація виконання етапів роботи;

- оцінка професійних можливостей соліста та їх розвиток;

- часткове виконання функції педагога зі спеціальності, диригента, режисера та ін.

Теоретик і практик концертмейстерської діяльності стверджує, що в музичній освіті коучінг може розумітися як унікальне ставлення до студента, з метою його 
підтримки, спрямоване на самостійну постановку цілей та пошук способів їх досягнення, яке максимально задіює його музичні та загальні здібності, що реалізують його професійно-технічний та творчий потенціал, сприяють ефективності та особистісному зростанню [8, с. 266].

Однією з актуальних тенденцій мистецької освіти на початку третього десятиліття XXI ст. є дистанційне навчання, а його активне використання як альтернативного традиційному в умовах загрози поширення коронавірусної інфекції $\epsilon$ не лише виправданим, а й необхідним. У зв’язку з цим виникла гостра проблема пошуку нових технологій навчання та їх використання в діяльності концертмейстерів. Наприклад, дієвим способом допомоги майбутньому музиканту в процесі вивчення твору є запис аудіофайлу партії супроводу.

Перспективами подальшого дослідження означеної проблематики $є$ аналіз педагогічної діяльності концертмейстера в контексті особливостей його підготовки в закладах музичної освіти та власне його участі в навчальному процесі як викладача в закладах мистецької освіти України.

Висновки. Сучасний етап у педагогіці концертмейсерської діяльності характеризується наявністю сформованих та розроблених спеціалістами різних напрямів науки основних понять, науково-методичних принципів, методик системи художньоестетичного виховання майбутніх музикантів. Дослідження виявило, що проблематика педагогічної компетенції концертмейстера належить до числа актуальних проблем, оскільки кожен історичний етап розвитку суспільства, формуючи власні орієнтири мистецької педагогіки, висуває нові вимоги або модифікує чинні. Відповідно специфіка розвитку сучасної мистецької освіти передбачає трансформацію традиційних методів та підходів викладання з метою адаптування до вимог сучасних студентів, а також - до умов соціокультурного простору.

Проблеми концертмейстерської діяльності в контексті мистецької освіти на сучасному етапі визначаються характером та змістом умов, що характеризують життя сучасного суспільства. Перспективи розвитку педагогічної діяльності концертмейстера спрямовані на виховання у майбутніх митців найкращих художньо-естетичних якостей, створення в процесі навчання умов для всебічного розвитку особистості, задоволення 
професійних та духовних потреб, розвиток творчих здібностей та навичок художньодослідницької діяльності.

\section{References}

1. Barenboim, L.A. (1974). Musical pedagogy and performance. Leningrad: Music.

2. Bobrova, E. V., Buslova, E. V., Akhlestina, A. Yu. (2020). Actual problems of the professional activity of an accompanist in the context of modern music education. Culture and art in the modern educational space: Materials of the IV All-Russian scientific and practical conference (with international participation), dedicated to the 60th anniversary of the founding of music, pedagogical and art education at Kostroma State University. Resp. ed. and comp. T.V. Ludanov, ed. and comp. N. E. Musinova, pp. 21-27.

3. Gurgula, R. I., Efremova, I. M. (2021). Pedagogical aspect of training future pianistaccompanist. Pedagogy of formation of creative personality in higher and general education schools, no. 75, pp. 26-31. DOI https://doi.org/10.32840/1992-5786.2021.75-1.5.

4. Zorin, V. V. (2019). Pedagogical skills of pianist-accompanist. Gilea: scientific bulletin, Issue 145 (2), pp. 72-75.

5. Kalinina, V. D. (2015). Basic components and professional specification in the creative activity of the accompanist-pianist. Abstract of Ph.D. Saratov : Saratov State Conservatory named after L. V. Sobinov.

6. Kononenko, V. A. (2008). The art of accompanist in professional education of a music teacher. Abstract of Ph.D. Moscow : RAO "Institute of Art Education".

7. Kravets, M. V, Borisova, E. N. (2017). Psychological and pedagogical aspect of training a future pianist-accompanist in the context of a professional communicative environment. Scientific-methodical electronic journal "Concept", no. 3, pp. 127-133.

8. Kuritskaya, L. V. (2019). Coaching approach in working with students of the accompanist class. Manuscript. Tambov: Diploma, Vol. 12, Issue 11, pp. 265-269.

9. Pereverzeva, O. (2019). Pedagogical aspects of the professional activity of the accompanist in the general cultural and musical-aesthetic development of the future teacher of musical art. Pedagogical education: theory and practice, Issue 27, pp. 226-230.

10. Umrikhina, O., Podolyan, A. (2017). The role of pianist-accompanist in pedagogical education. Collection of scientific works of UDPU named after Pavel Tychyna, Issue 2, Part 2, pp. 286-295.

11. Shcherbinin, O. M. (2018). Professional activity of a musician-teacher: modern requirements and evaluation criteria. Scientific notes of NDU named after M. Gogol, no. 1, pp. $85-89$.

\section{Translation of the References to the Author's Language}

\section{Список використаних джерел}

1. Баренбойм Л.А. Музыкальная педагогика и исполнительство. Ленинград : Музыка, 1974. 335 с. 
2. Боброва Э. В., Буслова Е. В., Ахлестина А. Ю. Актуальные проблемы профессиональной деятельности концертмейстера в условиях современного музыкального образования. Культура и искусство в современном образовательном пространстве : Материалы IV Всероссийской научно-практической конференции (с международным участием), посвященной 60-летию основания музыкальнопедагогического и художественного образования в Костромском государственном университете. Отв. ред. и сост. Т.В. Луданова, ред. и сост. Н Е. Мусинова. 2020. С.21-27.

3. Гургула Р. I., Єфремова I. М. Педагогічний аспект підготовки майбутнього піаніста-концертмейстера. Педагогіка формування творчої особистості у вищій і загальноосвітній школах. 2021. № 75. С. 26-31. DOI https://doi.org/10.32840/19925786.2021.75-1.5.

4. Зорін В. В. Педагогічна майстерність піаніста-концертмейстера. Гілея: науковий вісник. 2019. Вип. 145(2). С. 72-75.

5. Калинина В. Д. Базовые компоненты и профессиональная спецификация в творческой деятельности концертмейстера-пианиста : автореферат дис. канд искусствоведения : 17.00.02 / Саратовская государственная консерватория имени Л. В. Собинова. Саратов, 2015. $15 \mathrm{c}$.

6. Кононенко В. А. Искусство концертмейстера в профессиональном образовании учителя музыки : автореферат дис. канд. педагогических наук : 13.00.08 / РАО «Институт художественного образования». Москва, 2008. 22 с.

7. Кравец М. В., Борисова Е. Н. Психолого-педагогический аспект подготовки будущего пианиста-концертмейстера в контексте профессиональной коммуникативной среды. Научно-методический электронный журнал «Концепт». 2017. № 3. С. 127-133.

8. Курицкая Л. В. Коучинговый подход в работе со студентами концертмейстерского класса. Манускрипт. Тамбов : Грамота, 2019. Т. 12. Вып. 11. С. 265-269.

9. Переверзєва О. Педагогічні аспекти професійної діяльності концертмейстера у загальнокультурному та музично-естетичному розвитку майбутнього вчителя музичного мистецтва. Педагогічна освіта: теорія і практика : збірник наукових праць. 2019. Вип. 27. C. $226-230$.

10. Умрихіна О., Подолян А. Роль піаніста-концертмейстера в педагогічній освіті. Збірник наукових праць УДПУ імені Павла Тичини / гол.ред. Мартинюк М.Т. Умань : ВПЦ «Візаві», 2017. Вип.2, Ч.2. С. 286-295.

11. Щербінін О. М. Професійна діяльність музиканта-педагога: сучасні вимоги та критерії оцінювання. Наукові записки НДУ ім. М. Гоголя. 2018. № 1. С. 85-89. 